\title{
Autonomic control of von Ebner's lingual salivary glands and implications for taste sensation
}

\author{
Suat Gurkan ${ }^{1}$ and Robert M. Bradley ${ }^{1,2}$ \\ ${ }^{1}$ Department of Oral Biology, University of Michigan, School of Dentistry, Ann Arbor, MI 48109 (U.S.A.) and ${ }^{2}$ The Department of \\ Physiology, School of Medicine, University of Michigan, Ann Arbor, MI 48109 (U.S.A.)
}

(Accepted 3 February 1987)

Key words: von Ebner's gland; Autonomic nervous system; Tongue; Circumvallate papilla; Salivary gland; Taste

\begin{abstract}
To learn the nature of the autonomic control of the serous lingual salivary glands of von Ebner, parasympathetic and sympathetic agonists were injected into rats, and the extent of depletion of the secretory granules in gland acini was measured. Injection of the $\beta$ adrenergic agonist isoproterenol caused a concentration-dependent reduction of the secretory granule content of the acinar cells. Injection of the $\beta$-adrenergic antagonist propranolol, combined with isoproterenol, blocked the reduction in secretory granule content seen with isoproterenol alone. Injection of the parasympathetic agonist carbachol also produced a concentration-dependent reduction in granule content of the acini. This reduction was partially blocked by injection of atropine, and completely blocked by injection of atropine and propranolol. $\beta$-Adrenergic and parasympathetic agonists alone did not cause total degranulation of the acini. However, this was achieved by injection of both agonists. It is concluded that protein secretion in von Ebner's glands is under both sympathetic and parasympathetic nervous control. It is hypothesized that the glands contain two sets of granules with different compositions, each under the control of either the parasympathetic or sympathetic nervous system. Because von Ebner's glands are closely associated with taste buds and because the glands supply the microenvironment of these taste buds the secretion of these glands may be very important in the mechanism of taste transduction.
\end{abstract}

\section{INTRODUCTION}

Von Ebner's lingual salivary glands are branched, tubuloalveolar, serous glands that secrete through multiple ducts into the clefts of the circumvallate and foliate papillae $e^{3,24,31}$. At the microscopic level the glands are essentially similar to other, protein secreting, exocrine glands that consist of ducts and acini filled with secretory granules ${ }^{16,28}$. In the rat, von Ebner's glands occupy a large triangular mass in the posterior tongue. The single circumvallate papilla is situated at the apex, and the foliate papillae are at the ends of the base, of the triangle.

The molecular receptor sites for gustatory stimuli on taste buds presumably are located on the microvilli of the taste cells ${ }^{4}$, which are bathed in saliva; therefore, it is probable that taste stimuli must traverse the saliva layer prior to interacting with active sites.
Moreover, $80 \%$ of the lingual taste buds are contained in the circumvallate and foliate papillae in the rat $^{21}$. Thus, the von Ebner's glands could play an important role in taste transduction in the majority of lingual taste buds.

There are very few studies on the properties of saliva from von Ebner's glands. Histochemical examination has revealed the presence of acid phosphatase $^{2,17,22}$, amylase ${ }^{30}$, and a non-specific esterase ${ }^{6}$. The secretory granules contain a peroxidase thought to regulate bacterial flora in the clefts of circumvallate and foliate papillae ${ }^{27}$. Biochemical analysis of the secretion of von Ebner's glands in a number of species has shown the presence of a lipase thought to initiate digestion of fat in the oral cavity and stom$\mathrm{ach}^{12-15}$. The composition of the secretion of von Ebner's glands is complex, therefore, and it is probable that these glands do not serve merely to rinse the

Correspondence: R.M. Bradley, Department of Oral Biology, School of Dentistry, Ann Arbor, MI 48109, U.S.A. 
clefts of the foliate and circumvallate papilla, as is often suggested ${ }^{20,29}$.

At present little is known concerning the neural control of von Ebner's glands. Presumably these glands are no different from other salivary glands which are under the control of the autonomic nervous system $^{26}$. Recently it has been shown, using retrograde tracing with horseradish peroxidase injected into the rat circumvallate papilla, that the parasympathetic secretomotor neurons controlling von Ebner's glands lie in the inferior salivatory nucleus in the medulla ${ }^{5}$; but nothing is known of the extent of sympathetic control. Getchell and Getchell ${ }^{11}$ examined the sympathetic control of Bowman's nasal glands, which are analogous to von Ebner's glands in that their secretion is intimately associated with chemoreceptors. By injection of sympathetomimetic drugs they were able to determine the extent of sympathetic control of the Bowman's glands by measuring secretory granule depletion. The purpose of the present investigation was to use similar techniques to measure the effect of sympathetic and parasympathetic agonists and antagonists on the acinar contents of von Ebner's glands and, therefore, determine the extent of autonomic nervous system control of these glands.

\section{MATERIALS AND METHODS}

Adult male Sprague-Dawley rats, weighing 140-160 g, were used. Rats were starved overnight to cause accumulation of secretory granules in the von Ebner's gland acini (Fig. 2a) and all experiments were started at $08: 30 \mathrm{~h}$ on the following morning. Animals were injected i.p. with either physiological saline or a drug(s) dissolved in saline. For each drug dose or combination of drugs 10 rats were used.

The following drugs or drug combinations were used. The $\beta$-adrenergic agonist, (+)-D-isoproterenol L-bitartrate (IPR) was injected at doses of 7.5, 15, 20,30 and $60 \mathrm{mg} / \mathrm{kg}$. D,L-Propranolol hydrochloride, a $\beta$-adrenergic antagonist, at a dose approximately

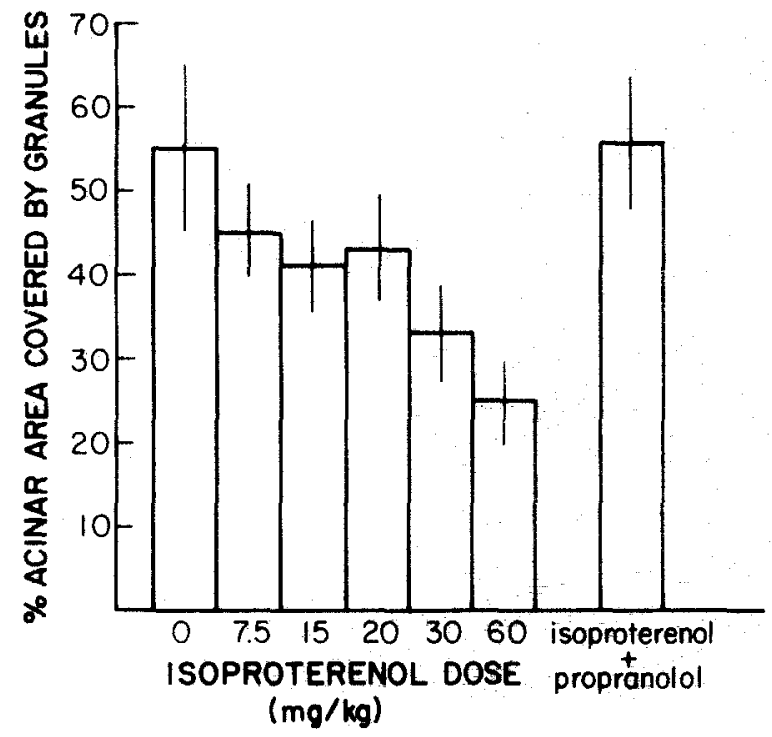

Fig. 1. Means and S.D. for area of granules of von Ebner's gland acini relative to increasing doses of isoproterenol, and propranolol followed by isoproterenol.

equimolar to $30 \mathrm{mg} / \mathrm{kg}$ IPR, was injected and followed $10 \mathrm{~min}$ later by $30 \mathrm{mg} / \mathrm{kg}$ IPR. To study parasympathetic control of the gland, carbamylcholine chloride (carbachol) was injected at doses of 100 , $200,300,400$, and $500 \mu \mathrm{g} / \mathrm{kg}$. The parasympathetic antagonist, atropine sulfate, was injected at 1.5 $\mathrm{mg} / \mathrm{kg}$, and followed $15 \mathrm{~min}$ later by $400 \mu \mathrm{g} / \mathrm{kg}$ carbachol. In a final group of rats, $60 \mathrm{mg} / \mathrm{kg}$ IPR and 400 $\mu \mathrm{g} / \mathrm{kg}$ carbachol were administered simultaneously. These drug doses were chosen because they have been shown to be effective in other studies of salivary glands ${ }^{1,11.32}$.

All rats were sacrificed by cervical dislocation, two hours after injection. The tongue was rapidly removed and a portion of the von Ebner's glands was dissected from the same anatomical region of the tongue in each animal. The gland tissue was fixed overnight in $4 \%$ glutaraldehyde and $1 \%$ paraformaldehyde in $0.1 \mathrm{M}$ phosphate buffer $(\mathrm{pH} 7.35)$ at $4{ }^{\circ} \mathrm{C}$, post-fixed with $1 \%$ osmium tetroxide for $1 \mathrm{~h}$ at room temperature, and embedded in Epon. Tissues were sectioned at $1 \mu \mathrm{m}$ and stained with $1 \%$ toluidine blue

Fig. 2. Light micrographs of von Ebner gland acini showing the effect of increasing doses of isoproterenol on reduction in secretory granule content. a: control acini - the arrows show that the area occupied by the secretory granules fills the whole acinus. $b: 7.5$ $\mathrm{mg} / \mathrm{kg}$. c: $15 \mathrm{mg} / \mathrm{kg}$. d: $20 \mathrm{mg} / \mathrm{kg}$. e: $30 \mathrm{mg} / \mathrm{kg}$. f: $60 \mathrm{mg} / \mathrm{kg}$ - the arrows indicate the much reduced area occupied by the secretory granules. g: $30 \mathrm{mg} / \mathrm{kg}$ isoproterenol $+42 \mathrm{mg} / \mathrm{kg}$ propranolol. $\mathrm{Bar}=10 \mu \mathrm{m}$. 

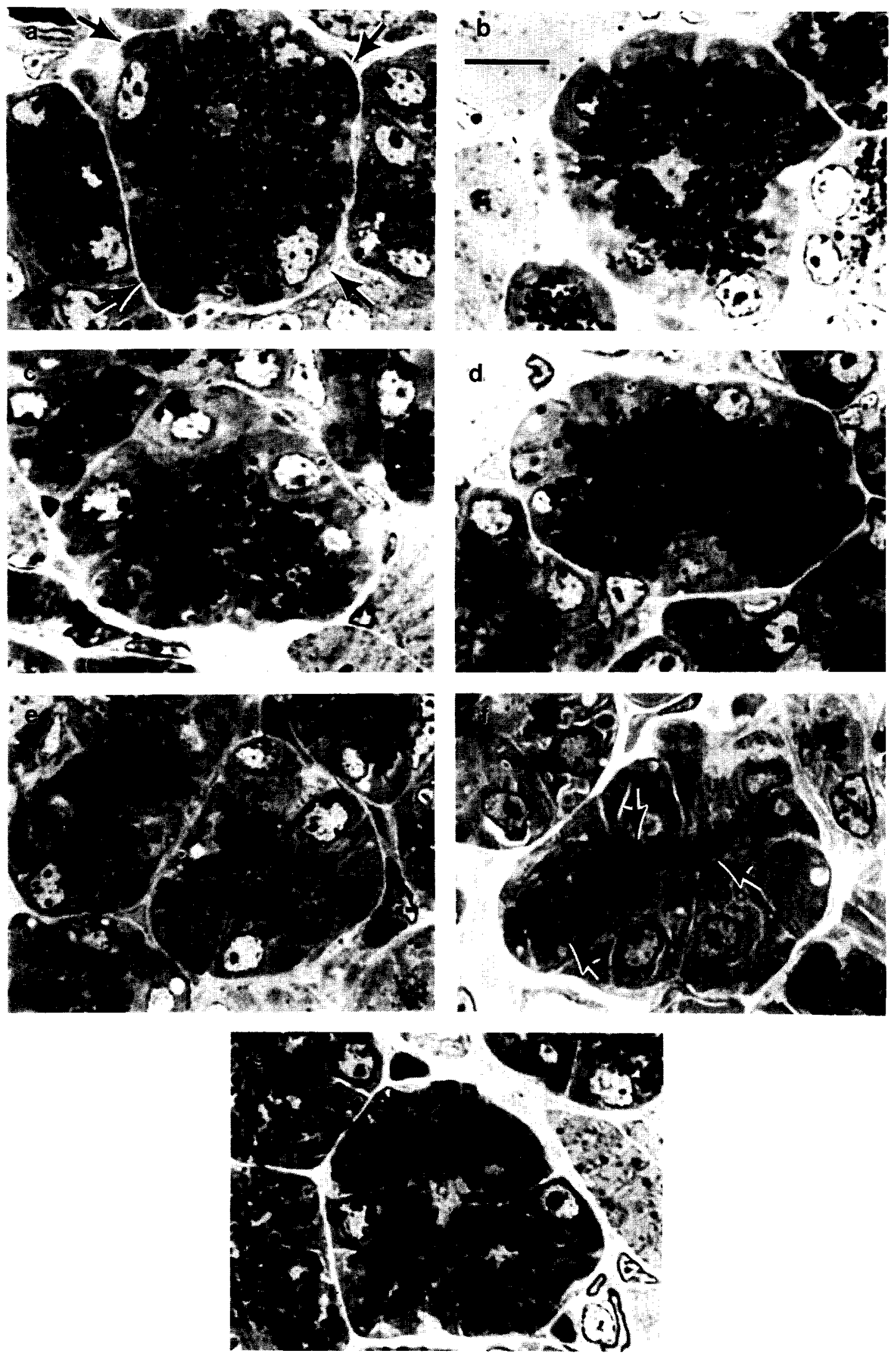
in $1 \%$ aqueous sodium borate for $45 \mathrm{~s}$. For each rat, random cross-sections of 5 acini were selected for black-and-white photomicroscopy at $100 \times$ magnification. Measurements of acinar and secretory granulue area were made from $4 \times 5$ in. photographs using computerized planimetry. Next the percentage of the total acinar area occupied by the granules was calculated. Then for each rat a mean percentage for the 5 acini was calculated.

\section{RESULTS}

As illustrated in Fig. 1 isoproterenol produced a dose-dependent depletion in secretory granules $\left(F_{6,69}=72.7, P<0.0001\right)$. The secretory granules in control acini occupied the whole of the cell cytoplasm but during depletion the granules migrated toward the cell apices and the secretory lumen (see arrows in Fig. 2). Post-tests demonstrated that all doses effected a depletion that was significantly different from controls $(P<0.0001)$. Doses of $7.5,15$ and 20 $\mathrm{mg} / \mathrm{kg}$ produced a similar degree of depletion, and the higher doses of 30 and $60 \mathrm{mg} / \mathrm{kg}$ produced significantly greater depletion than any lower doses (Fig. 1). However, even with the highest dose, complete depletion was never achieved (Figs. 1 and $2 f$ ). When

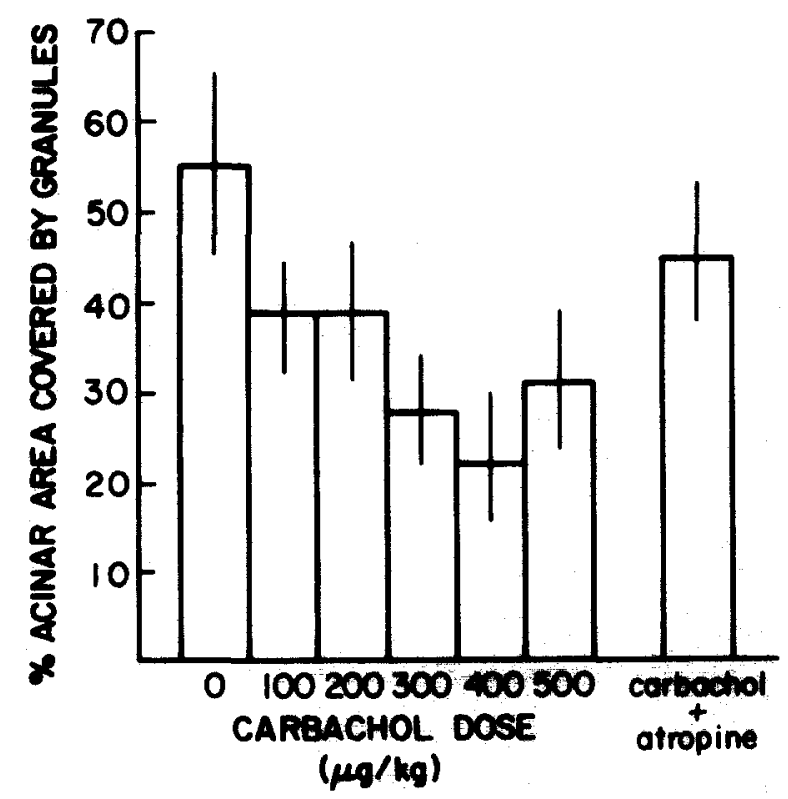

Fig. 3. Means and S.D. for area of granules of von Ebner's gland acini relative to increasing doses of carbachol, and carbachol followed by atropine. the agonist and antagonist were given together there was no significant depletion compared to controls ( $P$ $>0.10$ ) (Figs. 1 and $2 g$ ).

Carbachol also caused depletion of the secretory granules $\left(F_{6,69}=48.2, P<0.0001\right)$ (Fig. 3). All doses produced a significant degree of depletion compared with controls $(P<0.0001)$, but even the highest dose did not produce complete depletion (Figs. 3 and 4 e). Injection of the agonist with the antagonist (atropine) resulted in a significant reduction in granules of about $10 \%$ compared to controls $(P<0.0001)$ (Figs. 3 and $4 \mathrm{f})$.

Complete depletion of secretory granules was achieved by combining $\beta$-adrenergic and parasympathetic agonists (Fig. 5). Combination of the two most effective doses $(60 \mathrm{mg} / \mathrm{kg}$ IPR and $400 \mu \mathrm{g} / \mathrm{kg}$ carbachol) resulted in complete depletion in all acini, whereas combination of the two lowest doses (7.5 $\mathrm{mg} / \mathrm{kg}$ IPR and $100 \mu \mathrm{g} / \mathrm{kg}$ carbachol) produced complete depletion in some, but partial depletion in other, acini.

\section{DISCUSSION}

It is apparent from these results that von Ebner's glands are under the control of both the $\beta$-sympathetic and parasympathetic nervous system. Injection of either the $\beta$-sympathetic agonist IPR, or the parasympathetic agonist carbachol, reduces the secretory granule content of the acinar cells. The reductions are concentration dependent but reach a maximum at about $50 \%$ depletion. That is, depletion is never complete.

The depletion produced by IPR is completely blocked by the $\beta$-adrenergic agonist propranolol. However, the parasympathetic agonist atropine did not completely block the depletion produced by carbachol. Presumably this is due to the fact that carbachol is probably activating the sympathetic system via the cervical ganglion ${ }^{25}$. To demonstrate this, in two rats after the $\beta$-sympathetic system was blocked with propranolol, injection of carbachol and atropine caused no apparent degranulation.

As in the present study, $\beta$-adrenergic stimulation of Bowman's glands also resulted in degranulation but depletion was never complete. The proportion of the area occupied by secretory granules in the acinar cells of Bowman's glands was reduced by $41 \%$ in the 
superficial and $39 \%$ in the deep gland acini ${ }^{11}$.

The results in von Ebner's and Bowman's glands are different from results obtained in other salivary glands. Injection of IPR causes total granule depletion in the parotid gland of the rat ${ }^{19}$, and significant reduction in the amylase content of rat parotid glands
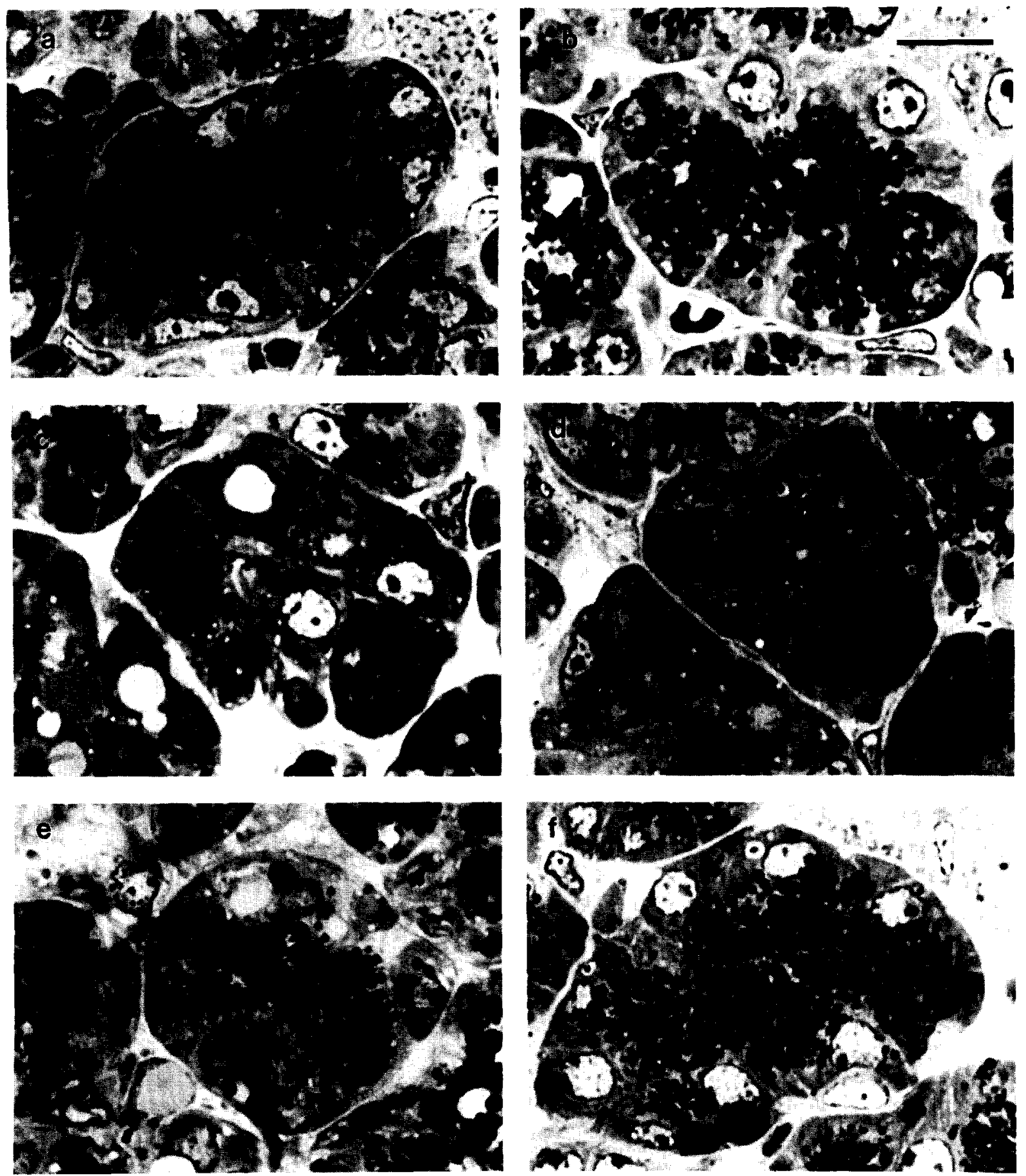

Fig. 4. Light micrographs of von Ebner's gland acini showing the effect of increasing doses of carbachol on reduction in secretory granule content. a: $100 \mu \mathrm{g} / \mathrm{kg}$. b: $200 \mu \mathrm{g} / \mathrm{kg}$. c: $300 \mu \mathrm{g} / \mathrm{kg}$. d: $400 \mu \mathrm{g} / \mathrm{kg}$. e: $500 \mu \mathrm{g} / \mathrm{kg}$. f: $400 \mu \mathrm{g} / \mathrm{kg}$ carbachol $+1.5 \mathrm{mg} / \mathrm{kg}$ atropine sulphate. $\mathrm{Bar}=10 \mu \mathrm{m}$. 


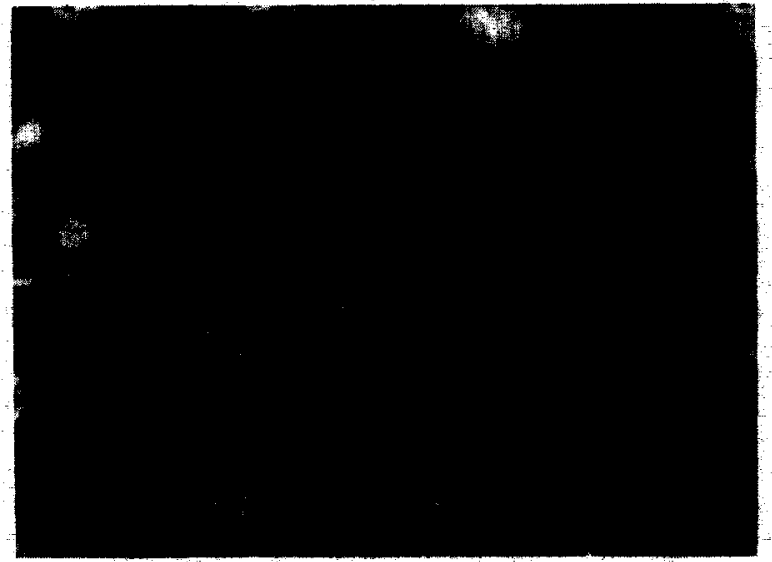

Fig. 5. Light micrograph of a von Ebner gland acinus after injection of $60 \mathrm{mg} / \mathrm{kg}$ isoproterenol $+400 \mu \mathrm{g} / \mathrm{kg}$ carbachol. Bar $=$ $10 \mu \mathrm{m}$.

is only achieved by the stimulation of the $\beta$-adrenergic receptors at the acini ${ }^{25}$. Thus, when measured as amylase concentration and the extent of degranulation, there seems to be general agreement that protein secretion in salivary glands is elicited chiefly by sympathetic nerves. In saliva secreted in response to parasympathetic impulses, the concentration of amylase is low and degranulation does not seem to be conspicuous ${ }^{9}$. Von Ebner's and Bowman's glands do not seem to follow these general rules, but because salivary glands are characterized by diversity of function it is not surprising that these glands are functionally different from many others.

Interactions between sympathetic and parasympathetic nerves in other salivary glands are not uncommon, however ${ }^{9}$. For example, a high flow rate of saliva evoked by parasympathetic stimulation is greatly reduced if sympathetic vasoconstrictor activity diminishes the blood supply to the gland ${ }^{8}$. Not all glands have a dual innervation, but when they do, sympathetic stimulation superimposed on parasympathetic stimulation causes an acceleration of the flow compared to parasympathetic stimulation alone $^{10}$. These findings are related to the effects of interactions on flow rate of saliva. For von Ebner's glands the interaction between parasympathetic and sympathetic stimulation results in secretion of protein, since a combination of sympathetic and parasympathetic agonists resulted in total degranulation.

These results have important implications for taste transduction. The superficial, acellular compartment of saliva covers the surface of the epithelium containing taste buds of the circumvallate and foliate papillae. Taste stimulants have to cross this compartment to reach the receptor membranes on the taste bud microvilli. A number of events could, therefore, take place before the taste stimulant reaches the microvillar membranes. These include differential solubility of the tastant in the saliva, diffusion of the tastant to the receptor membranes, interaction of the tastant with components of the saliva, and interaction of the tastant with the receptor membrane. Therefore the composition of the saliva is important in the control of the initial events of taste transduction. The salivary composition consists of proteins and electrolytes dissolved in water which change with the level and type of gland stimulation. Initiation of gland activity is under control of the autonomic nervous system via a number of brainstem reflex connections, one of which involves the gustatory system.

Afferent neural activity from taste buds in the circumvallate and foliate papillae travels in the glossopharyngeal nerve to the first central relay in the nucleus of the solitary tract. Immediately ventral and mesial to this nucleus are the secretomotor cells innervating the salivary glands $s^{5,7}$. This close apposition would facilitate neural interactions between afferent sensory input from the taste buds and efferent secretomotor activity to the salivary glands. This is especially important for von Ebner's glands which are so intimately associated with taste buds. Thus taste activity could initiate secretion and secretion could modulate taste activity by altering the microenvironment of the taste receptor membranes. It is also possible that the type of afferent activity could control composition of the saliva. It is known that stimulation of the tongue with sucrose produces a saliva with a high concentration of amylase, whereas stimulation with citric acid produces a much lower concentration of amylase $\mathrm{e}^{18,23}$. Thus, different taste stimuli can alter salivary composition. A possible explanation for this is that taste fibers responding best to different tastants are connected to different secretomotor efferents thereby altering the composition of the saliva produced by the glands.

It is apparant, therefore, that there is interaction between von Ebner's glands and taste buds of the circumvallate and foliate papillae. The extent of this in- 
teraction remains to be determined but it is important to consider the microenvironment of the receptor membranes in the overall transduction process. This is especially pertinent for the taste buds of the circumvallate and foliate papillae which are so intimately associated with von Ebner's glands. Perhaps it is time to consider the circumvallate and foliate papillae as gustatory organs made up of receptors and

\section{REFERENCES}

1 Abe, K. and Dawes, C., The effect of electrical and pharmacological stimulation on the types of protein secreted by rat parotid and submandibular glands, Arch. Oral Biol., 23 (1978) 367-372.

2 Baradi, A.F. and Bourne, G.H., Gustatory and olfactory epithelia, Int. Rev: Cytol., 2 (1953) 289-330.

3 Baumgartner, E.A., The development of the serous glands (von Ebner's) of the vallate papillae in man, Am. J. Anat., 22 (1917) 366-376.

4 Beidler, L.M., Taste receptor stimulation, In J.A.V. Butler, H.E. Huxley and R.E. Zirkle (Eds.), Progress in Biophysics and Biophysical Chemistry, XII, Pergamon, New York, 1962, pp. 107-151

5 Bradley, R.M., Mistretta, C.M., Bates, C.A. and Killackey, H.P., Transganglionic transport of HRP from the circumvallate papilla of the rat, Brain Research, 361 (1985) 154-161.

6 Burstone, M.S., Esterase of the salivary glands, J. Histochem. Cytochem., 4 (1956) 130-139.

7 Contreras, R.J., Gomez, M.M. and Norgren, R., Central origins of cranial nerve parasympathetic neurons in the rat, J. Comp. Neurol., 190 (1980) 373-394.

8 Emmelin, N., Nervous control of salivary glands. In C.F. Code (Ed.), Handbook of Physiology. Section 6: Alimentary Canal. Volume II. Secretion, American Physiological Society, Washington, DC, 1967, pp. 595-632.

9 Emmelin, N., Interactions between sympathetic and parasympathetic nerves in the control of the salivary glands, In C.M. Brooks, K. Koizumi and A. Sato (Eds.), Integrative Functions of the Autonomic Nervous System, University of Tokyo Press, Tokyo, 1979, pp. 5-32.

10 Emmelin, N. and Gjörstrup, P., The physiology of salivary myoepithelial cells, In N.A. Thorn and O.H. Petersen (Eds.), Secretory Mechanisms of Exocrine Glands. Alfred Benzon Symposium VII, Munksgaard, Copenhagen, 1974, pp. 29-41.

11 Getchell, M.L. and Getchell, T.V., $\beta$-adrenergic regulation of the secretory granule content of acinar cells in olfactory glands of the salamander, J. Comp. Physiol., 155 (1984) 435-443.

12 Hamosh, M. and Burns, W.A., Lipolytic activity of human lingual glands (Ebner), Lab. Invest., 37 (1977) 603-608.

13 Hamosh, M. and Hand, A.R., Development of secretory activity in serous cells in the rat tongue, Dev. Biol., 65 (1978) 100-113.

14 Hamosh, M., Klaeveman, H.L., Wolf, R.O. and Scow, R.O., Pharyngeal lipase and digestion of dietary triglyceride in man, J. Clin. Invest., 55 (1975) 908-913.

15 Hamosh, M. and Scow, R.O., Lingual lipase and its role in the digestion of dietary lipid, J. Clin. Invest., 52 (1973) 88-95. glands in an interacting structure.

\section{ACKNOWLEDGEMENTS}

This work was supported by N.I.H. Grant NS21764. We thank Drs. Marilyn L. Getchell and Thomas V. Getchell for help and advice on the technical aspects of this work.

16 Hand, A.R., The fine structure of von Ebner's gland in the rat, J. Cell. Biol., 44 (1970) 340-353.

17 Iwayama, T. and Nanda, O., Histochemical observation of the phosphatases of the tongue, with special reference to taste buds, Arch. Histol. Jpn., 28 (1967) 149-151.

18 Kemmer, T. and Malfertheiner, P., Der differenzierte Einfluss der Geschmacksqualitäten 'suss' und 'sauer' auf die Parotidsekretion, Res. Exp. Med., 183 (1983) 35-46.

19 Lillie, J.H. and Han, S.S., Secretory protein synthesis in the stimulated rat parotid gland, J. Cell. Biol., 59 (1973) $708-721$.

20 Mattern, C.F.T., Daniel, W.A. and Henkin, R.I., The ultrastructure of the human circumvallate papilla 1. Cilia of the papillary crypt, Anat. Rec., 167 (1970) 175-182.

21 Miller, I.J. Jr., Gustatory receptors of the palate. In Y. Katsuki, M. Sato, S.F. Takagi and Y. Oomura (Eds.), Food Intake and the Chemical Senses, University of Tokyo,Tokyo, 1977, pp. 173-185.

22 Mira, E., Cytochemical localization of oxidative and hydrolytic enzymes in von Ebner's glands, Acta Oto-Laryngol., 59 (1965) 88-96.

23 Newbrun, E., Observations on the amylase content and flow rate of human saliva following gustatory stimulation, J. Dent. Res., 41 (1962) 459-465.

24 Oppel, A., Gustatory stimulation, In Lehrbuch der Vergleichenden Mikroskopischen Anatomie der Wirbeltiere, Vol. 3, Mundhöle, Bauchspeicheldrüse und Leber, Fischer, Jena, 1900, pp. 212-228

25 Schneyer, C.A., Role of sympathetic pathway in secretory activity induced in rat parotid by feeding, Proc. Soc. Exp. Biol. Med., 147 (1974) 314-317.

26 Schneyer, L.H. and Emmelin, N., Salivary secretion. In E.D. Jacobson and L.L. Shanbour (Eds.), Gastrointestinal Physiology, University Park, Baltimore, 1974, pp. $183-226$.

27 Taylor, T. and Erlandsen, S.L., Peroxidase localization in von Ebner's gland in man, J. Dental Res., 52 (1973) 635.

28 Testa Riva, F., Cossu, M., Lantani, M.S and Riva, A., Fine structure of human deep posterior lingual glands, $J$. Anat., 142 (1985) 103-115.

29 Toyoshima, K. and Shimamura, A., The occurrence of ciliated cells in the peripapillary trench of the rat tongue, Anat. Rec., 195 (1979) 301-310.

30 Tremblay, G. and Charest, J., Modified starch gel film method for the histochemical localization of amylase activity, J. Histochem. Cytochem., 16 (1968) 147-148.

31 Von Ebner, V., Die Acinösen Drüsen der Zunge und ihre Beziehungen $z u$ den Geschmacksorganen, Leuschner, Graz, 1873, pp. 1-66.

32 Young, J.A., Martin, C.J. and Weber, F.D., The effect of a sympatho- and a parasympathomimetic drug on the electrolyte concentrations of primary and final saliva of the rat submaxillary gland, Pflügers Arch., 37 (1971) 285-302. 